\title{
Fabrication and Characterization of Solid-state Electrochemical Sensor for the Determination of Ni(II)
}

\author{
Rajan Timilsina ${ }^{1}$, Haribhakta $\mathrm{Oli}^{2}$ and Amar Prasad Yadav ${ }^{3 *}$ \\ ${ }^{I}$ Department of chemistry, Tri-Chandra Multiple Campus, Kathmandu, Nepal \\ 2 Amrit Campus, T.U, Lainchour, Kathmandu, Nepal \\ ${ }^{3}$ Central Department of Chemistry, Tribhuvan University, Kirtipur, Nepal \\ E-mail: amar2y@yahoo.com
}

\begin{abstract}
An electrochemical sensor was prepared by using solid state electrode membrane based on $\mathrm{NiS} / \mathrm{Ag}_{2} \mathrm{~S}$ by using nitrate of nickel dissolving in appropriate amount of sodium sulfide with silver nitrate by coprecipitation method. The sensor electrode prepared based on the NiS/ $\mathrm{Ag}_{2} \mathrm{~S}$ at the ratio of 1:2 moles was prepared. The prepared sensor electrode can be used for the determination of trace amount of Ni(II) ions. The Nernstian slope for the sensor electrode was $-6.1429 \mathrm{mV} /$ decade. Then this was improved by using $\mathrm{NaNO}_{3}$, ascorbic acid and methanol and Nernstian slope was improved to be $-27.114 \mathrm{mV} /$ decade. The prepared electrode can be used within long $\mathrm{pH}$ range between 2 to 7 . In a reliable storage, the life time of sensor electrode was six months with which fast response was observed. Thus, prepared sensor electrodes can be used for the determination of $\mathrm{Ni}(\mathrm{II})$.
\end{abstract}

Key words: sensor, nickel, potentiometry, pH range, selectivity coefficient.

\section{Introduction}

Although Nickel is found in trace in quantity, environmentally it is so important in environment protection that it is highly toxic element ${ }^{1}$. It is present in the environmental sample of water as a contaminant coming from urban or industrial waste pollution. It is highly toxic even at low concentration and interference with various matrix, the determination of accurate, precise and selective for Nickel determination is required.

Different modern methods and precise technique such as inductively coupled plasma atomic emission spectrometric (ICP-AES), graphite furnace atomic absorption spectrometry (GFAAS), flame atomic absorption spectrometry (FAAS) have been developed for the determination of $\mathrm{Nickel}^{2,3}$. These methods are very expensive for the determination, therefore cannot be afford easily for developing countries and need more training, knowledge and sample pretreatment is required; also, onsite determination is not possible with these instruments ${ }^{4}$. On comparison with other techniques, electrochemical sensors are very attractive, ease of preparation, stability of their response, low ohmic response and no need internal solution ${ }^{4}$.

${ }^{*}$ Corresponding author 
Among these methods, potentiometric electrochemical sensor using specific ion sensor are simple, more precise, high rate, more accuracy, low cost and non-destructive and can be used as in-situ technique. In the construction of these sensors, various design can be constructed depending for precise and more economic technique. Among various constructions, solid back contact can be the best design in the sensor; working and accuracy of sensor can be improved ${ }^{5}$. Similarly, on using solid back contact, the efficiency, precision and sensitivity of sensor can be enhanced. It reduces the changing the concentration of internal solution which is directly proportional to the potential given by the sensor electrode $\mathrm{e}^{6,7}$.

In this technique, the ion selective electrode $\mathrm{NiS} / \mathrm{Ag}_{2} \mathrm{~S}$ was prepared by the co-precipitation method at the ratio of 1:2 moles. The sensor membrane is characterized by X-ray diffraction pattern ${ }^{6,8}$. A conventional sensor electrode is modified by removing internal solution by solid back contact. Here, solid back contact was used to remove internal solution from the conventional ion selective electrode which removes the problem created by the changing in the concentration of the internal solution. The ion selective electrode prepared by solid state back contact and used for the determination of nickel in environmental samples. The investigation of effective parameters was done and good selectivity towards nickel ion was observed. Thus, prepared electrode can be used for fast simple method for the determination of nickel content in environmental samples with low concentrations.

\section{Experimental Methods}

\section{Reagents and solutions}

All reagents and solutions were of analytical grade and used without any further purification. Nickel nitrate, silver nitrate and sodium sulfide were purchased from Merk company. All solution prepared were from deionized distill water.

\section{Preparation of ion selective membrane}

For the synthesis of $\mathrm{NiS} / \mathrm{Ag}_{2} \mathrm{~S}$ ion selective membrane, $0.8589 \mathrm{~g}$ of nickel nitrate was taken in a $50 \mathrm{ml}$ distilled water, $2.008 \mathrm{~g}$ of silver nitrate was taken in other $50 \mathrm{ml}$ distilled water and $1.037 \mathrm{~g}$ of sodium sulfide taken in $50 \mathrm{ml}$ distilled water. $\mathrm{Ni}\left(\mathrm{NO}_{3}\right)_{2}$ solution and $\mathrm{AgNO}_{3}$ solutions from two separate burettes were added to $\mathrm{Na}_{2} \mathrm{~S}$ solution containing beaker at constant rate on stirring constantly by magnetic stirrer maintained at 50 ${ }^{\circ} \mathrm{C}$ to $60{ }^{\circ} \mathrm{C}$ in a water bath for about an hour to obtain the complete precipitation of NiS and $\mathrm{Ag}_{2} \mathrm{~S}$.

$$
\mathrm{Ni}\left(\mathrm{NO}_{3}\right)_{2}+2 \mathrm{AgNO}_{3}+2 \mathrm{Na}_{2} \mathrm{~S} \quad \rightarrow \quad \mathrm{NiS} \downarrow+\mathrm{Ag}_{2} \mathrm{~S} \downarrow+4 \mathrm{NaNO}_{3}
$$

Thus, obtained black precipitate was filtered with $4 \mathrm{G}$ sintered glass crucible and washed several times with distilled water for free from sulfide. The precipitate was dried in hot air oven at $110{ }^{\circ} \mathrm{C}$ followed by grinding and sieved over 150-micron sieve to obtain the fine powder of uniform sized particles. The formation of $\mathrm{NiS} / \mathrm{Ag}_{2} \mathrm{~S}$ was confirmed by XRD analysis. About $1.5 \mathrm{~g}, 1.5 \mathrm{~mm}$ thickness and $1 \mathrm{~cm}$ diameter $\mathrm{NiS}-\mathrm{Ag}_{2} \mathrm{~S}$ pressed pellet was prepared by IR pellet making die on giving pressure of 10 tones $/ \mathrm{cm}^{2}$ for about 15 minutes and dried over hot air oven at $100{ }^{\circ} \mathrm{C}$ for about an hour to remove the trapped air. The pellet was polished in different grades of SiC abrasive paper and finally in 2000 grit sized paper in order to make the surface smooth.

\section{Apparatus}

The electrode used was obtained at room temperature with the $\mathrm{Ni}$ (II) ion selective electrode and calomel electrode $\left(\mathrm{Hg} / \mathrm{Hg}_{2} \mathrm{Cl}_{2}\right)$ as reference electrode. In between working and reference electrode a high 
impedance multi-meter (BK Precision model-389, Taiwan) was connected. For drying hot air oven was used (Narang Scientific Works Pvt. Ltd). The pH measurement made by $\mathrm{pH}$ meter (model-276) and the solutions were stirred with the help of the magnetic stirrer (Stuart Scientific,UK). The ultra-sonicator (Branson-2510) was also used for removing the loose particles and for preparation of the pellets out of the prepared co-precipitate, an IR-based machine was used manufactured in UK.

\section{Preparation of nickel ion selective electrode}

During the fabrication of the nickel ion selective electrode a PVC rod of $10 \mathrm{~cm}$ long and $1.5 \mathrm{~cm}$ diameter was used as outer body of the sensor in which a groove of about $1.1 \mathrm{~cm}$ wide and about $2.5 \mathrm{~mm}$ depth was made and for the electrical connection a hole was drilled at the center throughout the length of the polyethylene rod. For the electrical connection with the membrane sensor i.e. back contact with pellet, a thin copper tape of about $1.0 \mathrm{~cm}$ in width was made with about $12 \mathrm{~cm}$ long copper wire soldered to it. The copper disc was then inserted inside the polyethylene rod for copper back-contact and the pellet membrane was smeared very thin with silver paste on one side and then attached to the silver disc into the groove of the rod. The electrode with the membrane was left for 30 minutes for the silver paste to dry and the space around the sensor membranes were then fixed with the help of epoxy resin and left for overnight for the solidification.

\section{Electrode conditioning and Emf measurement}

The sensors were finally conditioned for $24 \mathrm{hrs}$. by soaking into a solution containing $1.0 \times 10^{-3} \mathrm{M}$ $\mathrm{Ni}\left(\mathrm{NO}_{3}\right)_{2}$ solution. The electrodes were rinsed by deionized distilled water then polished in 2000 grit sized $\mathrm{SiC}$ abrasive paper for smooth before potential measurements. In all solutions the potential was measured versus calomel electrode $\left(\mathrm{Hg} / \mathrm{Hg}_{2} \mathrm{Cl}_{2}\right)$ as reference electrode. The electrochemical cell assembly for potential measurements can be represented as:

$$
\mathrm{Pt}(\mathrm{Hg}) / \mathrm{Hg}_{2} \mathrm{Cl}_{2} \text {, (KCl) // Test solution }\left(\mathrm{Ni}^{2+}\right), \mathrm{ISBA} / \mathrm{Ni}(\mathrm{II}) \mathrm{ISE}
$$

\section{Sample preparation}

For the purpose of carrying out the experiment, all the reagents in this work were of AR grade or of LR grade. The stock solutions were prepared using distilled water. The stock solutions were diluted at required concentration prior to the experiment.

\section{Results and Discussion}

\section{Characterization of co-precipitate}

The obtained compound was confirmed to be $\mathrm{Ag}_{2} \mathrm{~S} / \mathrm{NiS}$ by matching all the peaks obtained in the XRD of Ni(II) ISE with the JCPDS data card no. 75 - 0613 for NiS and JCPDS data card no-14-0072 for $\mathrm{Ag}_{2} \mathrm{~S}$. The JCPDS database showed the presence of binary phase of existing as separate phase of NiS and $\mathrm{Ag}_{2} \mathrm{~S}$ and obtained all peaks were assigned according to the JCPDS database. The peaks for NiS were obtained at 34.7(002), 37.88(220) and that for $\mathrm{Ag}_{2} \mathrm{~S}$ were at 29.01(111), 30.93(111) and. 31.7(101). This shows that the co-precipitates prepared were in pure state and polycrystalline in nature with metallic nickel. 


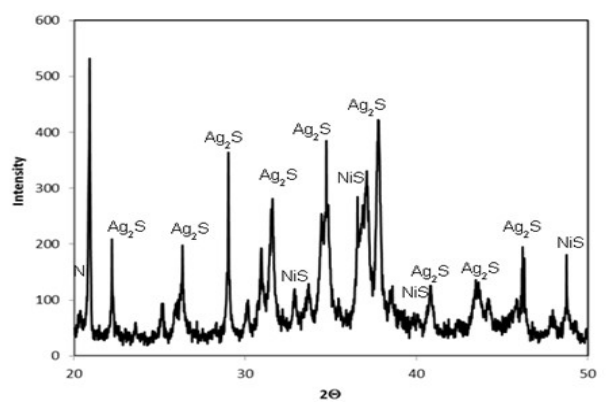

Figure 1: $\mathrm{XRD}$ pattern of $\mathrm{Ag}_{2} \mathrm{~S}-\mathrm{NiS}$ co-precipitate

\section{Working pH range of the electrodes}

The working $\mathrm{pH}$ of the test solution having concentration of $1.0 \times 10^{-3} \mathrm{M}$ was determined at the room temperature. From the graph, it was observed that the potential response was not affected with in the $\mathrm{pH}$ range in between 2.0-7.0, beyond this $\mathrm{pH}$ range of the solution; the potential response of the electrode was seen deviating considerably and the potential drift occurred. Hence, this $\mathrm{pH}$ range of 2.0 to 7.0 was taken as the working $\mathrm{pH}$ range of the $\mathrm{Ni}$ (II) sensor as no interference from $\mathrm{H}^{+}$ions or $\mathrm{OH}^{-}$ions was observed. The cause of considerable drift at the acidic solution i.e. at lower $\mathrm{pH}$ may be due to the fact that the membrane of the electrode could be protonated to some extent. It is noteworthy that in alkaline solution, the observed drift at higher $\mathrm{pH}$ values could be due to the hydrolysis of nickel in the test solution.

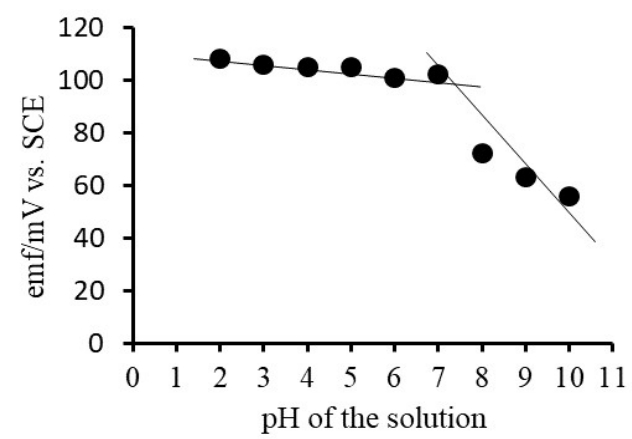

Figure 2: Effect of the $\mathrm{pH}$ of the test solution of $1.0 \times 10^{-3} \mathrm{molL}^{-1} \mathrm{Ni}$ (II) ions on the potential response of the $\mathrm{Ni}(\mathrm{II})$ ion-selective electrode

\section{Direct potentiometry study}

The potential response of the solid-state sensor of $\mathrm{NiS} / \mathrm{Ag}_{2} \mathrm{~S}$, acting as a working electrode, along with saturated calomel electrode was recorded as a function of change in the concentration of the test solution of $\mathrm{Ni}\left(\mathrm{NO}_{3}\right)_{2}$ of fixed $\mathrm{pH}$ of 6.5. Theoretically, the cell emf of the $\mathrm{Ni}(\mathrm{II})$ ion selective electrode can be related to the concentration of the $\mathrm{Ni}(\mathrm{II})$ ions present in the test solution as:

$$
\mathrm{E}_{\text {cell }}=\mathrm{E}_{\text {const }}+0.0292 \log \left[\mathrm{Ni}^{2+}\right]
$$

The outcome of the direct potentiometry measurements with $\mathrm{Ni}$ (II) ion selective electrode for $\mathrm{Ni}$ (II) ions was $-6.1 \mathrm{mV} /$ decade on plotting the experimental values of the emf of the electrochemical cell as a 


\section{J. Nepal Chem. Soc., Vol. 37, 2017}

function of different concentrations of $\mathrm{Ni}\left(\mathrm{NO}_{3}\right)_{2}$ solution. For the bivalent cations, theoretical Nernstian slope is $29.58 \mathrm{mV} /$ decade as obtained by the Nernst equation. It seemed that without the presence of any anti-oxidants and ionic strength adjuster buffer the value of Nernstian slope of fabricated $\mathrm{Ni}$ (II) ion selective electrode was greatly affected and resulted in much less than the predicted theoretical Nernstian slope. The good outcome of the lower detection limit by the nickel nitrate solution and the significant improvement in the Nernstian slope with the addition of ascorbic acid to the test solution with sodium nitrate solution was obtained. The graphs show a good Nernstian slope which is very nearer to the theoretical value. In addition of these improvements, the experimental data were also found to have less scattering and all the points fell in a linear slope with coefficient of determination $\left(\mathrm{R}^{2}\right)$ value of 0.997 .

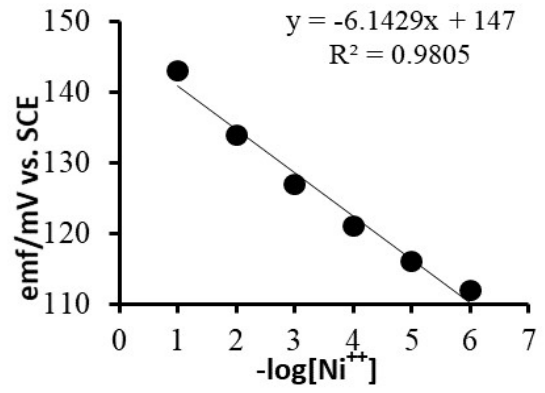

(a)

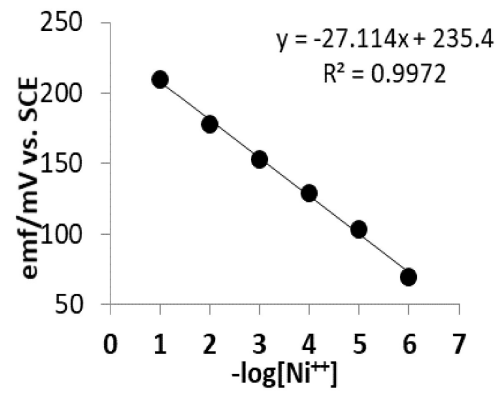

(b)

Figure 3: Plot of potential vs. concentration (a) only $\mathrm{Ni}\left(\mathrm{NO}_{3}\right)_{2}$ solution and (b) in a mixture of $\mathrm{Ni}\left(\mathrm{NO}_{3}\right)_{2}$, ascorbic acid and $\mathrm{NaNO}_{3}$ for electrode

Comparing this electrode with the commercially available electrode, the $\mathrm{Ni}$ (II) ion selective electrode fabricated in this study seemed to perform as good as the commercially available electrode having the lower detection limit of $1.0 \times 10^{-6} \mathrm{M}$ and the Nernstian slope above $20 \mathrm{mV} / \mathrm{decade}$. Therefore, the solidstate sensor prepared in the laboratory worked well for the determination of $\mathrm{Ni}$ (II) ion concentration up to $1.0 \times 10^{-6} \mathrm{M}$ concentration.

\section{Potentiometric titration}

The applicability of the $\mathrm{NiS} / \mathrm{Ag}_{2} \mathrm{~S}$ ion selective electrode, as an indicator electrode for the potentiometric titration, was examined by titration of $5 \mathrm{~mL}$ of $1.0 \times 10^{-2} \mathrm{M}$ concentration of $\mathrm{Ni}\left(\mathrm{NO}_{3}\right)_{2}$ solution against $1.0 \times 10^{-2} \mathrm{M}$ concentration of EDTA. During titration, $20 \mathrm{~mL}$ of water was added to the solution and $1 \mathrm{~mL}$ of EDTA solution was added to the nickel nitrate solution and the potential was recorded while stirring the solution.

The emf of the cell with respect to the concentration of $\mathrm{Ni}^{++}$and $\mathrm{S}^{-1}$ during potentiometric titration was shown by the equation below;

$$
\mathrm{E}_{\text {cell }}=\mathrm{E}_{\text {aggreg }}+0.0295 \log \left[\mathrm{Ni}^{++}\right] /\left[\mathrm{S}^{--}\right]
$$

The emf of the cell depended on the concentration ratio of $\left[\mathrm{Ni}^{++}\right] /\left[\mathrm{S}^{-}\right]$. When $\mathrm{Ni}^{++}$ion solution was titrated against EDTA solution from burette, observed emf of the cell decreased for every addition of EDTA solution. This was due to the decrease in free $\mathrm{Ni}^{++}$ions in the solution. At the equivalence point, 
there was dramatic decrease in observed emf because at that point nearly all the $\mathrm{Ni}^{++}$ions were consumed by EDTA solution to form Ni-EDTA complex. The equivalent point of the reaction is confirmed by the sudden change in potential. The sharp break point and the fast response time in the potentiometric titration of $\mathrm{Ni}$ (II) salt solution against EDTA corresponded to Ni-EDTA stoichiometry which showed that this sensor can be used for the determination of $\mathrm{Ni}(\mathrm{II})$ ions by potentiometric titration methods. Hence, $\mathrm{Ni}(\mathrm{II})$ ion selective electrodes can be used as an indicator electrode in potentiometric titration for the determination of $\mathrm{Ni}(\mathrm{II})$ ions even in low concentration range.

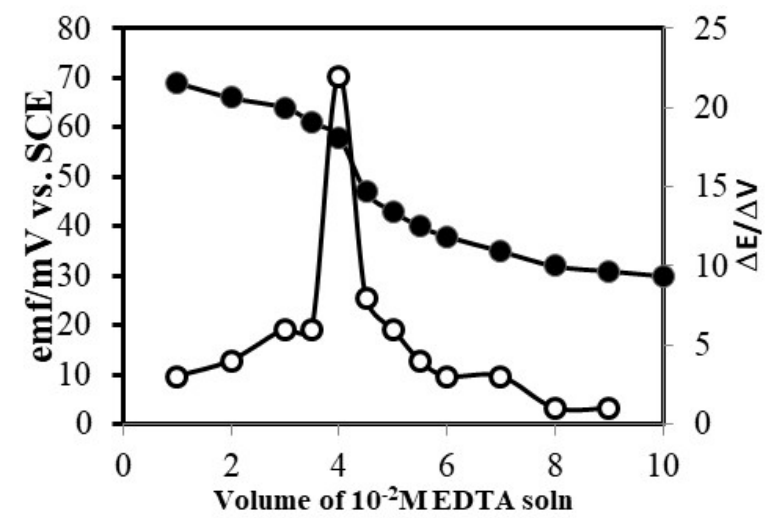

Figure 4: A Potentiometric titration curve of $10 \mathrm{ml} \mathrm{Ni}$ (II) ion solution $\left(1.0 \times 10^{-3} \mathrm{molL}^{-1}\right)$ with $1.0 \times 10^{-3} \mathrm{molL}^{-}$

${ }^{1}$ EDTA using the proposed membrane sensor as an indicator electrode

\section{Determination of leaching behavior of the membrane}

The leaching of the $\mathrm{NiS} / \mathrm{Ag}_{2} \mathrm{~S}$ electrode can be studied by determining the amount of $\mathrm{Ni}^{2+}$ ions dissolved in the aqueous solution from the membrane sensor. For the determination of the amount of the $\mathrm{Ni}(\mathrm{II})$ ions leached from the sensor membrane, the electrode was dipped in $5 \mathrm{~mL}$ of $1.0 \times 10^{-2} \mathrm{M}$ nickel nitrate solution which was diluted to make $25 \mathrm{~mL}$ by adding distilled water containing $\mathrm{NaNO}_{3}$ and ascorbic acid was added up to $3 \mathrm{hrs}$. Then, the test solution was titrated against $1.0 \times 10^{-2} \mathrm{M}$ EDTA solution.

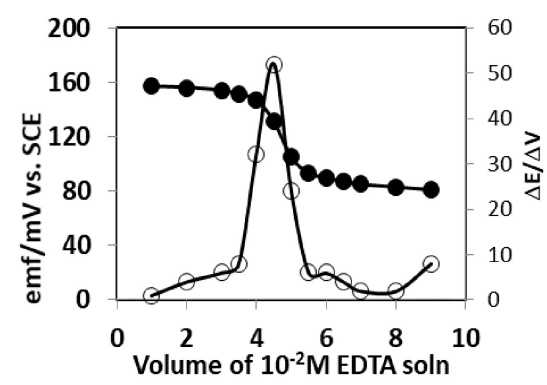

(a)

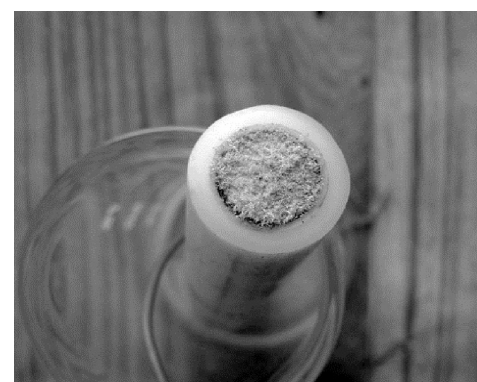

(b)

Figure 5: (a)Potentiometric titration curve of $5 \mathrm{~mL} \mathrm{Ni} i^{++}$ion solution $\left(1.0 \times 10^{-2}\right.$ moll $\left.{ }^{-1}\right)$ with $1.0 \times 10^{-2}$ moll ${ }^{-1}$ EDTA using the fabricated sensors as an indicator. (b) Spontaneous leaching of the membrane sensor after long storage in the moist environment 


\section{J. Nepal Chem. Soc., Vol. 37, 2017}

It can be estimated that for the consumption of $5 \mathrm{ml}$ of $1.0 \times 10^{-3} \mathrm{molL}^{-1} \mathrm{Ni}\left(\mathrm{NO}_{3}\right)_{2}$ solution, exactly $5 \mathrm{ml}$ solution of $1.0 \times 10^{-3} \mathrm{molL}^{-1}$ EDTA solution is required. But here, $1 \mathrm{ml}$ of excess volume of EDTA was consumed by the $\mathrm{Ni}\left(\mathrm{NO}_{3}\right)_{2}$ solution. This excess volume of EDTA consumed was proportional to the amount of $\mathrm{Ni}^{++}$ions dissolved from the sensor membrane in the aqueous solution for 3 hrs. Hence by calculation, $5.869 \times 10^{-5} \mathrm{~g}$ or $\left(4 \times 10^{-5} \mathrm{M}\right)$ of $\mathrm{Ni}^{++}$ions of the $\mathrm{Ni}(\mathrm{II})$ sensor membrane has been leached into the diluted aqueous solution of $\mathrm{Ni}\left(\mathrm{NO}_{3}\right)_{2}$ after dipping the electrode for $3 \mathrm{hrs}$. The leaching may be due to the setup of the concentration gradient of $\mathrm{Ni}^{++}$ion solutions in between the membrane sensor and the test solution.

In summary, the $\mathrm{NiS} / \mathrm{Ag}_{2} \mathrm{~S}$ ion selective electrode can be used as an indicator in the potentiometric titration for the determination of the $\mathrm{Ni}$ (II) ions dissolved in the test solution quantitatively and that such sensor should not be kept in nickel free solution for long time as it will lead to deterioration of the sensor membrane. The pellet of the $\mathrm{Ag}_{2} \mathrm{~S} / \mathrm{NiS}$ sensor when kept in the moist environment for about 6-7 months without any use was gradually leaching. This happened due to the storage of the electrode in the moist environment that facilitated the aerial oxidative leaching of the nickel present in the crystal lattice of the pellet as well as the hydration of the sensor membrane to give the greenish crystal of the nickel.

\section{Dynamic Response Characteristics}

The curves for the dynamic response of a $\mathrm{Ni}(\mathrm{II})$ sensors are obtained by the concentration from $1.0 \times 10^{-6} \mathrm{M}$ to $1.0 \times 10^{-1} \mathrm{M}$ of the $\mathrm{Ni}$ (II) salt solution and the potential was measured at the interval of 30 sec. till the equilibrium potentials are obtained. The concentration of the test solution was usually changed by the addition of higher concentration of $\mathrm{Ni}$ (II) salt solution to the test solution. The potential of the cell was observed to increase with the increase in the concentration of the test solution and the potential was fluctuating unless the equilibrium potential between the membrane of the electrode and the test solution was maintained. it was observed that the equilibrium potential has been set up within 3 minutes after the electrode was dipped into the test solution. This was usually the average time required for the electrode to reach a potential within $1 \mathrm{mV}$ or $2 \mathrm{mV}$ of the final equilibrium value after successive immersion in a series of $\mathrm{Ni}^{++}$ion solutions, each having a 10-fold difference in concentration. This was usually the average time required for the electrode to reach a potential within $\pm 2 \mathrm{mV}$ of the final equilibrium value after successive immersion in a series of $\mathrm{Ni}^{++}$ion solutions, each having a 10 -fold difference in concentration.

This may be probably due to the fast interaction kinetics of $\mathrm{Ni}^{2+}$ ions of the test solution with the membrane sensor at the test solution/membrane interface. Good polishing for the smooth and plane surface and optimum preconditioning of the membrane electrode may also be responsible for giving very short response time.

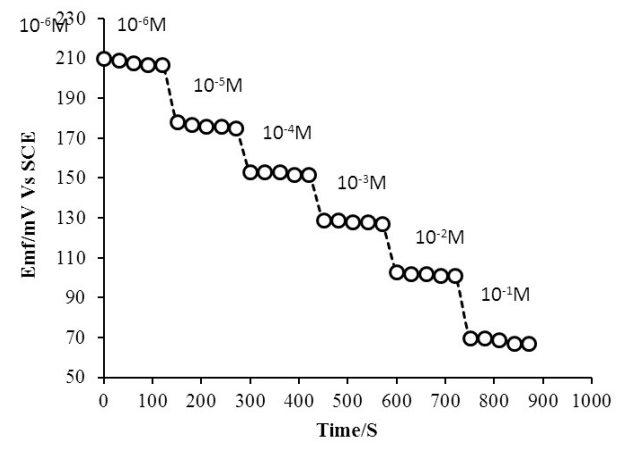

Figure 6: Dynamic response time of the Ni(II) sensor for step changes from low to high concentration of $\mathrm{Ni}^{++}$ions 


\section{Selectivity coefficient determination}

For the determination of selectivity coefficient of sensing electrode match potential method (MPM) is the recommended method for studying influence of interferences ion in the ion selective electrode by IUPAC. It is based on the measurement of specific activity of primary ion added to a reference solution. The selectivity coefficient for the $\mathrm{Ni}^{2+}$ ions was determined against the other interfering ions such as $\mathrm{Na}^{+}$, $\mathrm{K}^{+}, \mathrm{Cu}^{++}, \mathrm{Pd}^{++}$and $\mathrm{Cd}^{++}$. For this, the first change in potential upon changing the concentration of $\mathrm{Ni}\left(\mathrm{NO}_{3}\right)_{2}$ from $1.0 \times 10^{-4} \mathrm{M}$ to $1.0 \times 10^{-3} \mathrm{M}$ was measured into a reference solution by the standard addition of high concentration of $\mathrm{Ni}\left(\mathrm{NO}_{3}\right)_{2}$ solution. Then in the separate experiment, the interfering ion was added to an identical reference solution until the same change in the potential was recorded. In the match potential method, the selectivity coefficient $\mathrm{K}_{\mathrm{Pot}, \mathrm{MPM}}$ is given by the ratio of the resulting concentrations of the $\mathrm{Ni}^{2+}$ ions over the interfering ions. The selectivity coefficient $\mathrm{K}_{\text {pot, MPM }}$ of the Ni(II) ion selective electrode is given by:

$$
\mathrm{K}_{\mathrm{Pot}, \mathrm{MPM}}=\mathrm{a}_{\mathrm{Ni}}^{++} / \mathrm{a}_{\mathrm{B}}
$$

Where, $\mathrm{a}_{\mathrm{Ni}++}$ is the activity/concentration of the primary ion. $\mathrm{a}_{\mathrm{B}}$ is the activity/concentration of the interfering ions.

The interference of $\mathrm{Na}^{+}, \mathrm{K}^{+}, \mathrm{Cu}^{++}, \mathrm{Pd}^{++}$and $\mathrm{Cd}^{++}$was investigated and showed that they have no significant effect on the response to $\mathrm{Ni}$ (II) shown in table below.

Table 1: The selectivity coefficients of various interfering cations for $\mathrm{Ni}^{++}$membrane sensors

\begin{tabular}{|l|l|}
\hline Interfering ions & $\mathbf{K}_{\text {Pot,MPM }}$ \\
\hline $\mathrm{Na}^{+}$ & 0.9721 \\
\hline $\mathrm{K}^{+}$ & 0.9732 \\
\hline $\mathrm{Cu}^{++}$ & 0.9808 \\
\hline $\mathrm{Pb}^{++}$ & 0.9723 \\
\hline $\mathrm{Cd}^{++}$ & 0.9885 \\
\hline
\end{tabular}

\section{Method validation}

For the validation of this method, different types of standard reference material were used ${ }^{8-10}$. The samples were treated as mentioned and the Ni(II) content were analyzed by this method. This method can be considered as the reliable and accurate method for the determination of nickel in the environmental samples.

\section{Conclusions}

A sensor membrane was fabricated for the determination of nickel ion. The electrode composition was $\mathrm{NiS} / \mathrm{Ag}_{2} \mathrm{~S}$ at the ratio of $1: 2$ moles was prepared. Effect of $\mathrm{pH}$ on the electrode, potentiometric determination was studied. The electrode has a long-life time and a response time. A good selectivity among other ions to nickel ion was absorbed which makes the electrode a good candidate in environmental samples.

\section{Acknowledgements}

Authors are grateful to Central Department of Chemistry TU for laboratory facilities. 


\section{References}

1. Y.L.N. Murthy, B. Govindh, B.S. Diwakar, K. Nagalakshmi and R. Singh, Int. J. of Chem. Tech. Research, 2011, 3, 1285-1291.

2. A.C. Power and A. Morrin, Electroanalytical Sensor Technology, Publisher: InTech, 2013, 38.

3. G. Suresh, P. Dhanalakshimi and N.V.N. Naidu, Int. J. of Current Sciences, 2003, 23(3), 83.

4. F.H. Jeffery, J. Bassett, J. Mendham, R.C. Denny, Vogels Textbook of Quantitative Chemical Analysis, fifth edition, Addison Wesley Longman Inc. UK, 1989.

5. A.P. Yadav, Preparation and analytical study of some silver sulfide based ion-selective electrodes. A dissertation submitted to Central Department of Chemistry, Tribhuvan University, 1995.

6. K.R. Ojha, Preparation and Response characterization of all solid state sensor for Pb(II). A dissertation submitted to Central Department of Chemistry, Tribhuvan University, 2012

7. A.R. Elsalamouny, S.A. Elreefy and A.M.A. Hassan, Research J. of Chem. Sci., June 2012, 2(6), 38-42.

8. J. Mendham, R.C. Denney, J.D. Barnes, M.K.J. Thomas, Vogel's text book of quantitative chemical analysis, longman publication, $6^{\text {th }}$ edition, 2007, 540-550.

9. A.J. Bard, C.R. Faulkner, Electrochemical methods fundamentals and applications, second edition, USA, 74-82.

10. E. Bakker, L.V. Kochian, J.E. Shaff and M.A. Pineros, Electrolysis, 1998, 10, 938-941. 